NBER WORKING PAPER SERIES

\title{
FISCAL POLICY CAN REDUCE UNEMPLOYMENT: \\ BUT THERE IS A LESS COSTLY AND MORE EFFECTIVE ALTERNATIVE
}

\author{
Roger E. A. Farmer \\ Working Paper 15021 \\ http://www.nber.org/papers/w15021 \\ NATIONAL BUREAU OF ECONOMIC RESEARCH \\ 1050 Massachusetts Avenue \\ Cambridge, MA 02138
}

May 2009

This paper was prepared for the November 13-14, 2009 meeting of the Carnegie-Rochester Conference Series on Public Policy, "Fiscal Policy in an Era of Unprecedented Budget Deficits." The author gratefully acknowledges the support of NSF grant 0720839. I wish to thank Katrin Assenmacher-Wesche, Amy Brown, Larry Christiano, Anton Cheremukhin, Alain Delacroix, Martin Ellison, Peter Howitt, Masanori Kashiwagi, James Nason, Roberto Perotti, Valery Ramey and Andrew Scott for their comments on an early version of this paper and on a related paper that influenced the final draft. Thanks also to Leland E. Farmer for research assistance. The views expressed herein are those of the author(s) and do not necessarily reflect the views of the National Bureau of Economic Research.

NBER working papers are circulated for discussion and comment purposes. They have not been peerreviewed or been subject to the review by the NBER Board of Directors that accompanies official NBER publications.

(C) 2009 by Roger E. A. Farmer. All rights reserved. Short sections of text, not to exceed two paragraphs, may be quoted without explicit permission provided that full credit, including $\odot$ notice, is given to the source. 
Fiscal Policy Can Reduce Unemployment: But There is a Less Costly and More Effective Alternative

Roger E. A. Farmer

NBER Working Paper No. 15021

May 2009, Revised October 2009

JEL No. E2,E24

\begin{abstract}
$\underline{\text { ABSTRACT }}$
This paper uses a model with a continuum of equilibrium steady state unemployment rates to explore the effectiveness of fiscal policy. The existence of multiple steady state equilibria is explained by the presence of search and recruiting costs. I use the model to explain the current financial crisis as a shift to a high unemployment equilibrium, induced by the self-fulfilling beliefs of market participants about asset prices. I ask two questions. 1) Can fiscal policy help us out of the crisis? 2) Is there an alternative to fiscal policy that is less costly and more effective? The answer to both questions is yes.
\end{abstract}

Roger E. A. Farmer

UC, Los Angeles

Department of Economics

Box 951477

Los Angeles, CA 90095-1477

and NBER

rfarmer@econ.ucla.edu 


\section{Introduction}

Following the 2008 financial crisis, governments throughout the world increased the size of fiscal deficits in a coordinated attempt to revitalize their economies. The fact that policy makers resorted to discretionary fiscal policy has spurred renewed interest in theoretical models of its effect, following two decades in which the academic spotlight has been on new-Keynesian models of monetary policy.

For the past twenty five years, economists used the Real Business Cycle Model to understand business cycles. ${ }^{1}$ They used the new-Keynesian model to understand monetary policy. ${ }^{2}$ It has been understood for some time (see Baxter and King (1993) and Burnside, Eichenbaum, and Fisher (2004)) that the theoretical effects of fiscal policy in the Real Business Cycle model depend on the way it is financed. Research on the effects of fiscal policy in newKeynesian monetary models is relatively new.

Davig and Leeper (2009) and Christiano et al (2009) are two recent papers that have studied fiscal policy in the new-Keynesian model. A clear message from Davig and Leeper's research is that the potency of fiscal policy in this framework depends on the interaction between fiscal and monetary policy regimes. The same message follows from Christiano et al who use an insight from Eggersston and Woodford (2002) to show that fiscal policy can be highly effective if monetary policy has reached a zero interest rate lower bound. These results draw on an important property of new-Keynesian models: Output can deviate from potential output only if prices are slow to adjust.

This paper takes a different approach. I study the effects of fiscal policy in a model that I call old-Keynesian to differentiate it from new-Keynesian economics. ${ }^{3}$ The new-Keynesian model maintains the natural rate hypothe-

\footnotetext{
${ }^{1}$ Kydland and Prescott (1982), Long and Plosser (1983).

${ }^{2}$ Clarida, Galí, and Gertler (1999).

${ }^{3}$ The old-Keynesian model is developed more fully in Farmer $(2006,2008,2009,2010)$.
} 
sis. Deviations of output from potential output are temporary and have small welfare effects. In Farmer (2009) I develop an old-Keynesian model with very different properties. This model displays a continuum of steady-state unemployment rates. The natural rate hypothesis does not hold, and deviations of the unemployment rate from its optimal value may be permanent. These deviations are associated with large welfare losses that can easily exceed $20 \%$ of steady state consumption. In the old-Keynesian model, sticky prices have nothing to do with high unemployment and in a monetary version of the model (Farmer 2010) any inflation rate is consistent with any unemployment rate in the steady state.

\section{Explaining the Crisis}

An important feature of the financial crisis of 2008 was it's sudden onset. The value of worldwide assets fell by as much as $40 \%$ between September of 2008 and February of 2009, and although the market has since begun to recover, the loss of household wealth was substantial. Macroeconomic models where the equilibrium is uniquely determined by fundamentals cannot easily explain these events because there is no obvious candidate for the source of the shock. In contrast, the old-Keynesian model explains the crisis as a self-fulfilling drop in confidence in a model with a continuum of steady state equilibria.

I will argue in this paper that in 2008, a drop in confidence caused the economy to move from a low to a high unemployment equilibrium. I claim further, that this new equilibrium is sustainable as a steady state. If government does not actively intervene to correct the situation, there will be a permanent loss of output, proportional to the size of the drop in the stock market, that could easily amount to $20 \%$ of gdp in perpetuity.

I ask two related questions. First: Can fiscal policy help us out of the

crisis? Second: Is there an alternative to fiscal policy that is less costly and 
more effective? My answer to both questions is: Yes.

\section{Relationship with Existing Literature}

The existence of multiple equilibria in labor search models has been known for some time. It was suggested by Diamond (1982a, 1984) that this multiplicity might provide the basis for understanding why government should intervene to manage aggregate demand. This paper takes Diamond's argument further. I build on an observation by Howitt (1986), that search models with costly search and recruiting contain a continuum of equilibria and I construct a fully articulated dynamic general equilibrium model with this property that can be compared with more standard models of a macroeconomy.

Multiplicities exist in labor search models for two reasons. The first has to do with externalities in the recruiting process of the kind studied by Diamond (1982b), Mortensen (1984) and Pissarides (1984). The second has to do with a bilateral monopoly problem. Howitt and McAfee (1987) pointed out that this second problem leads, not just to a finite multiplicity of equilibria, but to the existence of a continuum of steady state unemployment rates.

The response in the literature to the Howitt-McAfee indeterminacy has been to argue that the model requires the addition of an additional fundamental equation based on preferences, technology and endowments. A variety of candidates have been proposed. The most common is the Nash bargaining solution that allocates rents between a firm and a worker by assuming a fixed bargaining weight. This solution was widely perceived to be problematic after Shimer (2005) showed that it leads to unreasonably large fluctuations in unemployment if the model is driven by productivity shocks.

Following Shimer's observation, a variety of alternatives have been proposed to the standard Nash bargaining approach including low worker bargaining weight by Hagerdorn and Manovskii (2008), and predetermined wages by Hall (2005a, 2005b) and Farmer and Hollenhorst (2004). The predeter- 
mined wage approach was developed further by Hall and Milgrom (forthcoming), Gertler and Trigari (forthcoming) and Gertler, Sala and Trigari (forthcoming), who added more complicated dynamic bargaining structures to explain the observed sluggish movement of wages in data.

This paper builds on Farmer (2009) where I propose a new approach. Instead of searching for a fundamental explanation to close an indeterminate model of the labor market, I close the model with the assumption that firms produce as many goods as are demanded. Demand, in turn, depends on beliefs of market participants about the future value of assets. By embedding the indeterminate labor search market into an asset pricing model, I show that the unemployment rate can be explained as a demand-constrained equilibrium where the indeterminacy of steady state equilibria is resolved by assuming that the beliefs of market participants are self-fulfilling.

\section{What's New in this Paper?}

In Farmer (2009), I assumed the existence of a representative agent. As a consequence, I showed that fiscal policy is ineffective and cannot be used to restore full employment. In contrast, population demographics in the current paper are based on work by Olivier Blanchard (1985) who developed a tractable model in which fiscal policy is effective. ${ }^{4}$ Blanchard refers to this as the perpetual youth model since it makes the simplifying assumption that the probability of death is independent of age.

The perpetual youth model captures an important idea in a simple way. Government debt is net wealth to the community because a government transfer to the current population, financed by issuing debt, increases the wealth of current generations at the expense of future generations who incur higher taxes to pay the interest on the debt. This property is in contrast to

\footnotetext{
${ }^{4}$ Blanchard's work was extended by Philippe Weil (1989). Their analysis is based on a paper by Menahem Yaari (1965).
} 
that of the popular representative agent model that has become the standard vehicle for studying business cycles. In that model, government debt is not net wealth because the single representative agent fully discounts the future tax burden of current transfers. This property, dubbed Ricardian Equivalence by Robert Barro (1974), has become the benchmark for most recent macroeconomic models.

In the model I develop in this paper, the fact that government debt is net wealth has important consequences for the real interest rate and for employment. If the government makes a transfer to the current population, consumers spend more on goods and services because the transfer increases the net present value of their labor income. In contrast to Walrasian models, this increase in demand moves the economy to a new equilibrium with less unemployment and a higher real interest rate.

\section{The Environment}

In this section I describe the economic environment that underlies my theory of multiple labor market equilibria. Much of this is a repeat of the model described in Farmer (2009). Since I take a non-standard approach to the labor market, I have repeated the main arguments here in some detail. In addition to developing a model of costly search and recruiting in the labor market, this section lays out the assumptions I make about the demographic structure. These assumptions are important and they lay the groundwork for my calculations of the potency of fiscal policy.

\subsection{Demographics}

I begin with a description of the population structure. I assume there are many generations alive at the same time. Each generation has a different consumption pattern which depends on its date of birth. But although there is heterogeneity at the individual level, two assumptions make aggregation 
possible. First, each generation has logarithmic preferences and hence their consumption is linear in wealth. Second, all agents have the same probability of death and hence there is a single concept of human wealth.

These two assumptions allow me to derive a set of equations in aggregate variables that describes the properties of an equilibrium. These equations are similar to those of the representative agent economy; but the representative agent's Euler equation is replaced by an aggregate consumption equation in which income and wealth affect steady-state consumption.

Each household discounts the future with discount factor $\beta$. It survives into the subsequent period with probability $\pi$. Every period a measure $(1-\pi)$ of households dies and a measure $(1-\pi)$ of new households is created. These assumptions imply that the population is fixed and, without loss of generality, I will normalize its size to 1 . There is no bequest motive, no population growth, and no uncertainty, although these features can be added at the cost of a little extra algebra.

\subsection{Preferences}

Each household derives utility from consumption. Household expected utility is defined by the function,

$$
\max J_{t}^{h}=\sum_{s=t}^{\infty}\left[(\pi \beta)^{s-t} \log \left(c_{s}^{h}\right)\right], \quad t \geq h .
$$

The superscript $h$ on a variable $x_{t}^{h}$ indexes date of birth and the subscripts $t$ and $s$ are calendar time. Each household has a unit measure of members each with one unit of time. Hence the time endowment of the household has measure 1 . Time can be spent in market activities $H_{t}$, or in leisure $1-H_{t}$.

$$
H_{t} \leq 1
$$


Since leisure yields no utility this constraint will be binding in the social planning problem described in Section 6 and in the market equilibrium studied in Section 9.

\subsection{Two Technologies $t$}

There are two technologies, one for producing goods from labor and capital and one for moving workers from home to work. The manufacturing technology is represented by the constant-returns Cobb-Douglas function

$$
\bar{z}_{t}=\bar{K}_{t}^{\alpha} \bar{X}_{t}^{1-\alpha}
$$

A bar over a variable denotes an economy-wide aggregate. Here, $\bar{z}_{t}$ is output in physical units of the produced commodity, $\bar{K}_{t}$ is the number of units of capital allocated to the production of commodities, and $\bar{X}_{t}$ is the number of workers allocated to the task of producing goods. I use the symbols $\bar{z}_{t}$, $\bar{c}_{t}$ and $\bar{g}_{t}$ to represent aggregate production, consumption and government purchases measured in physical units and I assume that all commodities are consumed by households or by government,

$$
\bar{z}_{t}=\bar{c}_{t}+\bar{g}_{t}
$$

I assume there is a unit measure of households and I use $\bar{H}_{t}$ to represent the aggregate measure of workers who participate in the labor market. In period $t$, a measure $\bar{L}_{t}$ of workers will be employed and a measure $\bar{U}_{t}$ will be unemployed,

$$
\bar{H}_{t}=\bar{L}_{t}+\bar{U}_{t}
$$

Of the workers who are employed, a measure $\bar{X}_{t}$ is assigned to producing goods and $\bar{V}_{t}$ to the task of searching for new workers. Hence,

$$
\bar{L}_{t}=\bar{X}_{t}+\bar{V}_{t}
$$


The search technology is represented by the constant returns-to-scale Cobb-Douglas function

$$
\bar{L}_{t}=\bar{H}_{t}^{1 / 2} \bar{V}_{t}^{1 / 2} .
$$

Here, $\bar{H}_{t}$ is the measure of workers looking for a job in the economy as a whole.

The model is simplified by making the assumption that the entire labor force is fired and rehired every period. ${ }^{5}$ This strong assumption allows me to ignore the dynamics of labor adjustment whilst retaining the important idea that there is a labor market failure that leads to multiple labor market equilibria.

\section{The Social Planning Optimum}

What would a social planner do in this economy? Since households don't care about leisure, and since there is no way to transfer resources though time, the optimal plan will maximize output per period. Putting together equations (3) through (7) and recognizing that Equation (2) will bind at the optimum, the reduced form technology faced by a social planner can be described by the expression,

$$
\bar{z}_{t}=\bar{K}_{t}^{\alpha} \bar{L}_{t}^{1-\alpha}\left(1-\bar{L}_{t}\right)^{1-\alpha} .
$$

Since the economy contains one unit of non-reproducible capital and one unit of labor, the social planner would choose

$$
\bar{L}_{t}=1 / 2, \quad t=1, \ldots
$$

\footnotetext{
${ }^{5}$ Since the firm begins the period with no workers, and since workers are an essential input to recruiting, it might be argued that the firm can never successfully hire a worker. Since I will be thinking of the time period of the model as a quarter or a year, this assumption should be seen as a convenient way of representing the equilibrium of a dynamic process.
} 
to maximize welfare.

Although the solution that maximizes output per period is unique, the consumption allocation across households is not. There will be many social welfare functions each of which allocates consumption in different ways.

Since unemployment is equal to $50 \%$ for every choice of Pareto weights in the social welfare function, the unemployment rate that maximizes output per period is a natural choice for a definition of the natural rate of unemployment. It differs from that of Friedman (1968) who defines the natural rate to be the equilibrium unemployment rate in an economy with search frictions. Since there are many such equilibrium unemployment rates, using my definition of an equilibrium, Friedman's concept is ambiguous. ${ }^{6}$

\section{$7 \quad$ Markets}

This section describes assumptions about markets. I assume that production is decentralized and there are unit measures of two kinds of firms. Production firms hire labor in a search market that I will describe further below. Financial services firms own capital and government debt and offer annuities contracts to households.

\subsection{Production Firms}

Let $p_{t}$, be the price of a commodity, $w_{t}$ be the money wage and let $r r_{t}$ represent the rental rate. All prices are quoted in dollars, which serves as a unit of account. Each production firm solves the problem,

$$
\max _{\left\{K_{t}, L_{t}, X_{t}, V_{t}\right\}} p_{t} K_{t}^{\alpha} X_{t}^{1-\alpha}-w_{t} L_{t}-r r_{t} K_{t},
$$

\footnotetext{
${ }^{6}$ See the discussion in Farmer (2009). The fact that the natural rate is so high follows from the assumption that the entire labor force is rehired in every period. I have retained this assumption since it simplifies my exposition. Amy Brown (2010, expected), shows that when the assumption is replaced with a dynamic model of the labor market, the optimal employment rate drops to $3 \%$ for the same matching function used in this paper.
} 
subject to,

$$
\begin{gathered}
L_{t}=X_{t}+V_{t}, \\
L_{t}=q_{t} V_{t} .
\end{gathered}
$$

The typical firm chooses how much capital to rent, $K_{t}$, how many workers to hire, $L_{t}$, and how many of these workers to allocate to the production department, $X_{t}$, and the recruiting department, $V_{t}$. The absence of a bar over a variable denotes that it is associated with an individual firm. I consider symmetric equilibria for which $\bar{x}_{t}=x_{t}$ for any variable $x_{t}$ by integrating over the measure of firms.

The money price $p_{t}$, the money wage $w_{t}$ and the money rental rate $r r_{t}$ are taken as given. In one-commodity general equilibrium models it is typical to choose the consumption good as the numeraire and to set the money price of goods at 1 . Here, I choose instead to take labor to be the numeraire and I set $w_{t}=1$.

\subsection{Costly Recruiting and the Search Externality}

The variable $q_{t}$ that appears in Equation (12) is taken parametrically by each firm. It represents the number of additional workers that can be hired by a single worker allocated to the recruiting department and it is analogous to the labor market tightness variable in a standard search model. ${ }^{7}$ Substituting Equations (11) and (12) into (10) and defining

$$
\Theta_{t}=\left(1-1 / q_{t}\right)
$$

one obtains a reduced form expression for profit, $\Pi_{t}$ of a typical firm,

$$
\Pi_{t}=Z_{t}-L_{t}-r r_{t} K_{t}
$$

\footnotetext{
${ }^{7}$ Pissarides (1990, P. 7).
} 
where,

$$
Z_{t}=p_{t} \Theta_{t}^{1-\alpha} K_{t}^{\alpha} L_{t}^{1-\alpha} .
$$

represents the dollar value of output.

Equation (13) is essential to understanding what is different about this model from a Walrasian model with a spot market for labor. It represents an externality to the firm but is determined, in equilibrium, by aggregate labor market conditions. In Section 9 I show that in a demand constrained equilibrium, $\Theta_{t}$ is determined by the equation

$$
\Theta_{t}=\left(1-\bar{L}_{t}\right),
$$

where the bar denotes aggregate labor. The appearance of this term for aggregate employment in the production function of an individual firm explains the existence of Pareto inefficient equilibria. Individual firms do not take account of their influence on the aggregate labor market when they make their decision to allocate workers to the recruiting department. The presence of this externality invalidates the first welfare theorem of competitive equilibrium that provides the conditions under which competitive equilibria are socially optimal.

The profit maximizing firms will choose,

$$
\alpha Z_{t}=r r_{t} K_{t},
$$

and

$$
Z_{t}=\frac{1}{(1-\alpha)} L_{t} .
$$

Equations (17) and (18) are identical to the first order conditions that would hold in a competitive model with an auction market for labor. Equation (18) is the first order condition for labor. $w_{t}$ does not appear in this equation because I have chosen $w_{t}=1$ as the numeraire. 


\subsection{Financial Service Firms}

The second type of firm in this economy provides financial services. Financial services firms hold two types of assets: capital and government debt. They finance their acquisition of these assets by issuing financial contracts to households. These contracts provide a claim to the assets of the firms and, in addition, they insure the households against mortality risk. They are described below.

There is free entry into the financial services industry. A financial services company may purchases assets and issue liabilities. Consider a company in period $t$ that purchases $K_{t+1}$ units of capital and $B_{t+1}$ pure discount bonds, issued by the government. Let capital sell for price $p_{k, t}$ and let $Q_{s}^{t}$ be the price at date $s$ of a security that promises to pay one dollar at date $t$. A special case is a pure discount bond that sells for price $Q_{t}^{t+1}$.

The financial services company sells a contract to the household for price $p_{H, t}$. It promises to pay the household one dollar at date $t+1$ if and only if the household survives. How are the prices $p_{k, t}, Q_{t}^{t+1}$ and $p_{H, t}$ related to each other?

The assumption of no riskless arbitrage opportunities implies the following two equations,

$$
\begin{gathered}
\left(\frac{p_{k, t+1}+r r_{t+1}}{p_{k, t}}\right)=\frac{1}{Q_{t}^{t+1}} \equiv R_{t}, \\
p_{H, t}=\pi Q_{t}^{t+1} .
\end{gathered}
$$

The term $R_{t}$ is the gross real interest rate on government debt. ${ }^{8}$ Equation (19) asserts that the return to capital must equal the return to government debt in an economy with no aggregate risk. Equation (20) asserts that the household will pay price $\pi Q_{t}^{t+1}$ for a security that pays one dollar in period $t+1$ contingent on being alive. The factor $\pi$ reflects an annuity discount

\footnotetext{
${ }^{8}$ Since the wage is chosen as the numeraire and is set equal to one in every period, the real and the money rates of interest are the same.
} 
that is offered by competitive financial service firms as a consequence of the no arbitrage assumption.

\subsection{Government}

The government choose how much to spend, $G_{t}$, where

$$
G_{t}=p_{t} g_{t}
$$

is the dollar value of government purchases, and it levies a proportional tax $\tau_{t}$, on labor income. Since all labor is inelastically supplied, this tax is nondistortionary. I abstract from capital taxes although this could easily be added back into the model.

Government faces the sequence of constraints,

$$
\frac{B_{t+1}}{R_{t}}=B_{t}+G_{t}-\tau_{t} L_{t}, \quad t=s, \ldots
$$

together with the no-Ponzi scheme condition

$$
\lim _{T \rightarrow \infty} Q_{\tau}^{T} B_{T} \leq 0
$$

Since the first order conditions for labor imply that

$$
L_{t}=(1-\alpha) Z_{t},
$$

Equation (22) can also be written as follows,

$$
B_{t+1}=R_{t}\left(B_{t}+G_{t}-(1-\alpha) \tau_{t} Z_{t}\right), \quad t=\tau, \ldots
$$

Equations (25) and (23) can be combined to impose the following single 
infinite-horizon constraint on government choices,

$$
\sum_{t=\tau}^{\infty}\left[Q_{\tau}^{t} G_{t}\right]+B_{\tau} \leq \sum_{t=\tau}^{\infty} Q_{\tau}^{t}(1-\alpha) \tau_{t} Z_{t}
$$

A feasible government policy is a sequence $\left\{B_{\tau}, \tau_{t}, G_{t}\right\}_{t=\tau}^{\infty}$ that satisfies (26). I assume that the government picks a feasible policy and I will study how that policy affects employment and the interest rate in equilibrium.

\subsection{Households}

Household $h$ solves the problem,

$$
\max J_{t}^{h}=\sum_{s=t}^{\infty}\left[(\pi \beta)^{s-t} \log \left(c_{s}^{h}\right)\right], \quad t \geq h
$$

subject to

$$
\begin{gathered}
\pi Q_{s}^{s+1} A_{s+1}^{h}=A_{s}^{h}+\left(1-\tau_{s}\right) L_{s}-p_{s} c_{s}^{h}, \quad s=t, \ldots \infty \\
A_{t}^{h}=0 .
\end{gathered}
$$

Since agents have logarithmic preferences, they will choose to consume a fraction $(1-\beta \pi)$ of wealth in every period. That is

$$
p_{t} c_{t} \equiv C_{t}^{h}=(1-\beta \pi)\left[A_{t}^{h}+h_{t}^{h}\right]
$$

where human wealth $h_{t}^{h}$ is defined recursively by the expression,

$$
h_{t}^{h}=\left(1-\tau_{t}\right) L_{t}+\pi Q_{t}^{t+1} h_{t+1}^{h} .
$$

$C_{t}^{h}, A_{t}^{h}$ and $h_{t}^{h}$ are all measured in dollars. 


\section{The Model Summarized}

I am now ready to put together the pieces of a complete general equilibrium model of the economy. These pieces are represented by five equations that describe the behavior of five endogenous variables: Consumption, gdp, the interest rate, government debt and employment. This section summarizes each of them.

\subsection{Equation 1: Consumption}

The aggregate consumption equation (derived in Appendix A) has two com-

pound parameters, $\tilde{\beta}$ and $\tilde{\alpha}$. They are functions of the discount factor $\beta$ and the survival probability, $\pi$,

$$
\tilde{\beta}=\frac{1-\pi(1-\beta \pi)}{\pi}, \quad \tilde{\alpha}=\frac{(1-\beta \pi)(1-\pi)}{1-\pi(1-\beta \pi)} .
$$

Using: (1) the assumption that each household consumes a fixed fraction of wealth and (2) the fact that human wealth is independent of age; one can derive the following expression,

$$
C_{t}=\frac{1}{R_{t} \tilde{\beta}} C_{t+1}+\tilde{\alpha}\left(Z_{t}+p_{k, t}+B_{t}-(1-\alpha) \tau_{t} Z_{t}\right)
$$

where $C_{t}$ is the dollar value of aggregate consumption expenditure.

In the special case when the population is fixed, $(\pi=1)$, the model collapses to a representative agent economy and Equation (33) reduces to the consumption Euler equation of the representative household. When $0<\pi<1$, aggregate consumption depends not only on expected future consumption but also on income and wealth with a coefficient $\tilde{\alpha}$. 


\subsection{Equation 2: The Interest Rate}

The second equation of the model follows from combining Equation (17) with (19).

$$
R_{t-1}=\left(\frac{p_{k, t}+\alpha Z_{t}}{p_{k, t-1}}\right) .
$$

The left side of this expression is the gross real return to debt held between periods $t-1$ and $t$. The right side is the gross return to buying a unit of capital for price $p_{k, t-1}$ at date $t-1$. Since capital does not depreciate in this model it can be sold for price $p_{k, t}$ and it earns a rental return of $\alpha Z_{t}$ where proportionality follows from the assumption of a Cobb-Douglas technology.

\subsection{Equation 3: The Government Budget Constraint}

The third equation is the government budget constraint;

$$
B_{t+1}=R_{t}\left(B_{t}+G_{t}-\tau_{t}(1-\alpha) Z_{t}\right)
$$

I assume that government chooses a sequence $\left\{G_{t}, B_{t}\right\}_{\tau}^{\infty}$ and that taxes are chosen to ensure that

$$
\sum_{t=\tau}^{\infty}\left[Q_{\tau}^{t} G_{t}\right]+B_{\tau} \leq \sum_{t=\tau}^{\infty} Q_{\tau}^{t} \tau_{t}(1-\alpha) Z_{t}
$$

\subsection{Equation 4: The Gdp Accounting Identity}

Equation four is the gdp accounting identity,

$$
Z_{t}=C_{t}+G_{t}
$$

$Z_{t}, C_{t}$ and $G_{t}$ are all denominated in dollars. 


\subsection{Equation 5: The Aggregate Supply Curve}

The final equation is the first order condition for choice of labor,

$$
Z_{t}=\frac{1}{1-\alpha} L_{t}
$$

Since the money wage is equal to 1 , (labor is the numeraire), this equation describes the employment $L_{t}$ needed to meet any level of demand, $Z_{t}$, when $Z_{t}$ is measured in dollars. I call this equation the aggregate supply curve following Keynes (1936). ${ }^{9}$

\section{A Characterization of Equilibrium}

This section presents a definition of equilibrium. The definition is nonstandard since this is not a Walrasian model and not all markets are cleared by prices. To distinguish my equilibrium concept from that of a Walrasian economy, I refer to it as a demand constrained equilibrium. Before defining this concept formally, I begin by defining two preliminary concepts; the state of expectations and fiscal policy. ${ }^{10}$

The state of expectations is a self-fulfilling sequence of beliefs about future asset prices. This sequence is expected by agents in the model to occur with probability one. I will compare different perfect foresight equilibria in which this belief is correct. I will also consider shifts from one perfect foresight equilibrium to another and, when this occurs, I will assume that the shift

\footnotetext{
${ }^{9}$ Farmer (2010), discusses the relationship of this model to the concepts of aggregate demand and supply from The General Theory.

${ }^{10} \mathrm{I}$ have appropriated the term, demand constrained equilibrium, from work by Jean Pascal Benassy (1975), Jacques Dreze (1975) and Edmond Malinvaud (1977) who contributed to a literature on fixed-price economics that was developed in the 1970's. Although fixedprice models with rationing of the kind studied by these authors are sometimes called demand constrained equilibria; that is not what I mean here. Instead I will use the term to refer to the equilibrium of a particular kind of competitive search model. The common heritage of both usages of demand constrained equilibrium is the idea of effective demand from Keynes' General Theory.
} 
was unanticipated, At points like this, the perfect foresight assumption will be violated.

Definition 1 (State of Expectations) A state of expectations is a nonnegative sequence $\left\{p_{k, t}\right\}_{t=\tau}^{\infty}$ with a bound $b$ such that

$$
p_{k, t}<b,
$$

for all $t$.

In Farmer (2009) I derive an explicit value for the upper bound $b$ as a function of the parameters of the model and I show that an equilibrium, of the kind I define below, exists for all bounded asset price sequences. That paper did not introduce government policy which I define below.

Definition 2 (Fiscal Policy) A fiscal policy is a non-negative sequence $\left\{G_{t}\right.$, $\left.B_{t}, \tau_{t}\right\}_{t=\tau}^{\infty}$ and an initial debt level $B_{\tau}$. If there exists a fiscal policy such that the inequality

$$
\sum_{t=\tau}^{\infty} Q_{\tau}^{t} G_{t}+B_{\tau} \leq \sum_{t=\tau}^{\infty} Q_{\tau}^{t} \tau_{t}(1-\alpha) Z_{t}
$$

is satisfied, the fiscal policy is said to be feasible for price sequence $\left\{Q_{\tau}^{t}\right\}_{t=\tau}^{\infty}$.

The right side of (38) is the net present value of future taxes which puts an upper bound on the net present value of the government sector and bounds feasible expenditure plans. Given these definitions, a demand constrained equilibrium is a set of feasible values of the endogenous variables that is consistent with the behavioral assumptions of the model and with market clearing in every period.

Definition 3 (Demand Constrained Equilibrium) A demand constrained equilibrium is a state of expectations, $\left\{p_{k, t}\right\}_{t=\tau}^{\infty}$, a feasible fiscal policy $\left\{B_{\tau}\right.$, $\left.\left\{G_{t}, B_{t+1}, \tau_{t}\right\}_{t=\tau}^{\infty}\right\}$ and a sequence of prices and quantities $\left\{C_{t}, Z_{t}, R_{t}, L_{t}\right\}_{t=\tau}^{\infty}$ such that Equations (33), (34), (35), (36) and (37) are satisfied. 
With the exception of aggregate supply, Equation (37), these equations could equally well describe a Walrasian economy. The other four equations determine sequences of consumption, government expenditure, government debt and taxes. If one were to assume a Walrasian labor market with inelastic labor supply, the model would be closed with two equations:

$$
\begin{gathered}
Z_{t}=\frac{1}{1-\alpha} w_{t} L_{t} . \\
L_{t}=1 .
\end{gathered}
$$

These equations would determine employment and the money wage. The assumption of an exogenous sequence of asset prices, $\left\{p_{k, t}\right\}_{t=\tau}^{\infty}$ defines the numeraire in each period.

In the model of this paper, Equations (39) and (40) are replaced by (41) and (42),

$$
\begin{gathered}
Z_{t}=\frac{1}{1-\alpha} L_{t}, \\
w_{t}=1 .
\end{gathered}
$$

Now the numeraire is fixed by the assumption that the money wage equals 1 and the beliefs $\left\{p_{k, t}\right\}_{t=\tau}^{\infty}$ are beliefs about the value of capital in wage units. Variations in the value of aggregate demand pick out different values of employment and different demand constrained equilibria.

\section{Steady State Equilibria}

In this section, I focus on steady state equilibria by assuming that households form constant sequences of beliefs about the values of asset prices. Government follows a policy in which its budget is balanced and debt remains constant over time. The assumption that debt remains constant allows me to describe equilibria in which the economy jumps from one steady state equilibrium to another in response to a change in the state of expectations. 
Imposing the assumption that all variables are time independent, leads to the following five equations that must hold in a steady state equilibrium.

$$
\begin{gathered}
C\left(1-\frac{1}{R \tilde{\beta}}\right)=\tilde{\alpha}\left(p_{k}+B+(1-\tau(1-\alpha)) Z\right), \\
Z=\frac{p_{k}}{\alpha}(R-1), \\
\tau=\frac{1}{(1-\alpha) Z}\left[\frac{R-1}{R} B+G\right], \\
Z=C+G, \\
Z=\frac{1}{1-\alpha} L .
\end{gathered}
$$

The state of expectations is captured by the self-fulfilling belief that the stock market price will equal $p_{k}$. Taking $\left\{p_{k}, B, G\right\}$ as exogenous, this system describes five equations in the five unknowns $R, Z, C, L$ and $\tau$.

To facilitate the description and analysis of the model, define the decreasing function $H,\left(\frac{1}{(1-\tilde{\alpha}) \tilde{\beta}}, \infty\right) \rightarrow\left(\infty, \frac{\tilde{\alpha}}{1-\tilde{\alpha}}\right)$,

$$
H(R)=\frac{\tilde{\alpha} R \tilde{\beta}}{(1-\tilde{\alpha}) R \tilde{\beta}-1} .
$$

Using this definition, one can rearrange Equations (43) - (46) to give the following three reduced form steady state equations

Market Clearing (ME Equation): $\quad Z=H(R)\left(p_{k}+\frac{B}{R}\right)+G$,

No Arbitrage (NA Equation): $\quad Z=\frac{p_{k}(R-1)}{\alpha}$,

Tax Equation: $\quad \tau=\frac{1}{(1-\alpha) Z}\left(\frac{(R-1)}{R} B+G\right)$. 
Equations (49) and (50) can be solved for $\left\{R^{*}, Z^{*}\right\}$, the steady state values of the real interest rate and GDP as functions of expectations $p_{k}$ and government purchases $G$. Equation (51) defines the tax rate on labor income that sustains this as an equilibrium.

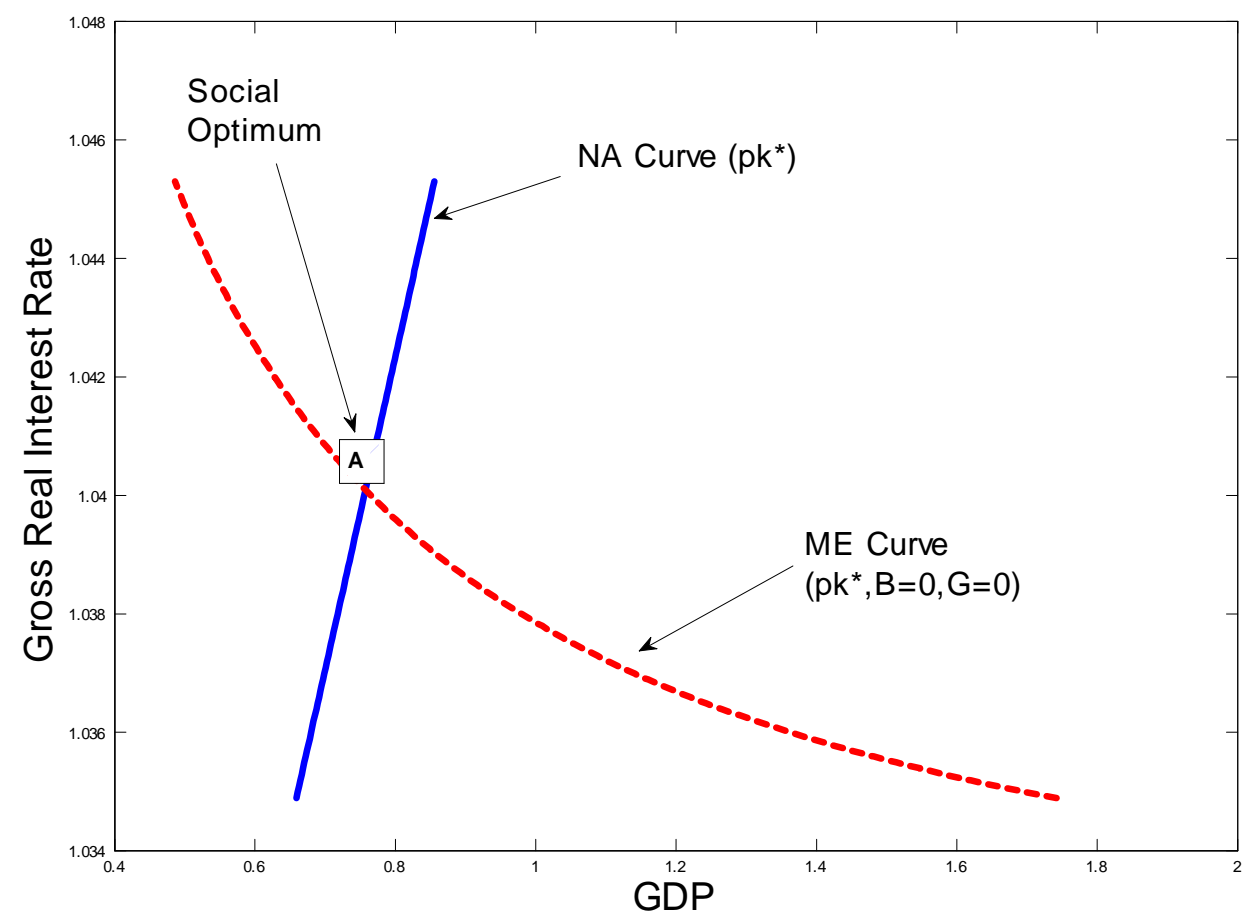

Figure 1: The Optimal Solution for $\mathrm{Z}^{*}$ and $\mathrm{R}^{*}$ (Baseline Calibration)

Figure 1 plots Equations (49) and (50) on a diagram. I refer to the curves on this diagram as the ME (market equilibrium) and NA (no arbitrage) equations. The Market Equilibrium curve is a downward sloping relationship between the real interest factor and the steady state dollar value of gdp. It's position depends on the relative price of capital, $p_{k}$, and on government policy, $G$ and $B$. The No Arbitrage curve is an upward sloping relationship between gdp and the real interest factor. The NA curve slopes up because 
the return to government debt must equal the return to capital. When GDP is higher, the rental rate on capital increases and the return on government bonds must also increase if households are to be indifferent between the two assets.

Figure 1 plots the ME and NA curves for a parameterization that I refer to as the baseline. In this calibration, the discount factor, $\beta$, is 0.97 , the survival probability, $\pi$, is 0.98 and labor's share of gdp to equal 0.66 . When $\pi=0.98$, the expected lifespan of a household is fifty years. Because I assume that workers are fired every period, the social planner would choose $L^{*}=0.5$. This implies $Z^{*}=0.76$ and a riskless interest rate of $4.0 \%$. I have drawn the figure for zero government spending, zero debt and a state of expectations, $p_{k}^{*}=6.4$, that supports the social optimum.

\section{Analysis of the Crisis}

In this section, I use the calibrated model to analyze the effectiveness of balanced budget fiscal policy. I assume that households spontaneously lose confidence in the stock market. They collectively come to believe that the value of capital in all future periods will be lower and will never recover. Given this permanent self-fulfilling shift in expectations, I ask first, What happens to the interest rate, output, and employment? Second, Can a balanced budget fiscal expansion restore full employment?

I study a balanced budget fiscal policy for two reasons. First, it is the easiest policy to study. Government debt is the only state variable in the model and, if debt is held fixed, the equilibrium response to a change in government purchases is an immediate shift from one steady state equilibrium to another. Second, a balanced budget policy does not involve a transfer of resources from one generation to another. Debt financing would yield higher welfare to existing generations and less crowding out of current consumption. Future generations would bear the cost in the form of higher taxes and lower 
consumption to pay for the profligacy of their ancestors.

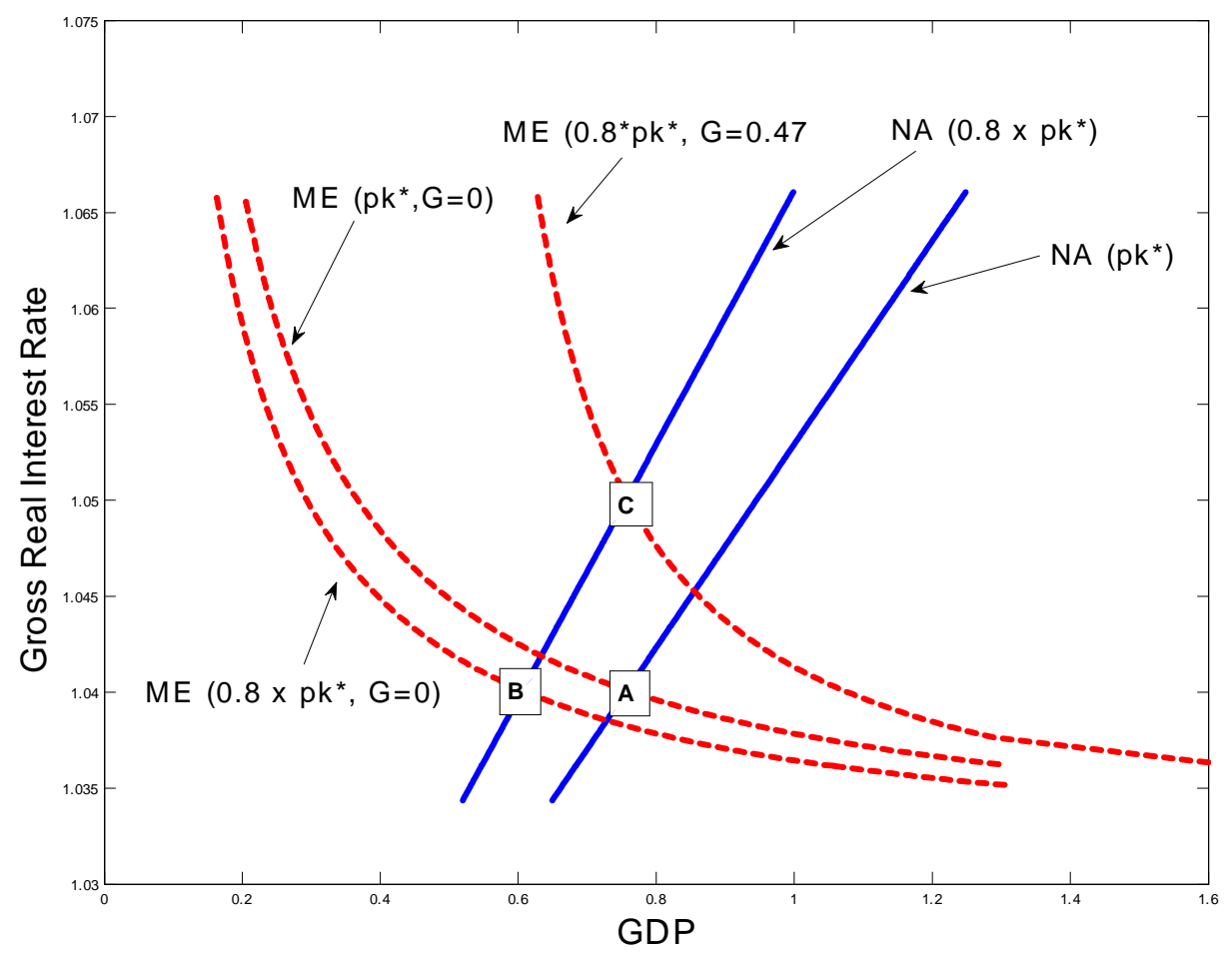

Figure 2: The Effects of a Crash in Expectations and a Subsequent Fiscal Expansion

Figure 2 illustrates the results of a market crash and a subsequent balanced budget intervention. All of the curves on the figure are drawn for government debt of zero. Government purchases are financed by a proportional tax on labor income. Point $\mathrm{A}$ is at the intersection of ME and NA curves, plotted for beliefs $p_{k}^{*}=6.4$ that support the social optimum in the baseline parameterization. ${ }^{11}$ This is the initial optimal state with zero debt and zero government purchases.

\footnotetext{
${ }^{11}$ I have posted the matlab code used to generate these graphs on my website at http://farmer.sscnet.ucla.edu.
} 
Point B illustrates the effect on the interest rate and GDP of a drop in beliefs about the value of capital from $p_{k}^{*}$ to $80 \%$ of its optimal value. In 2008, the market fell by much more than this. I have kept the analysis here to a drop of $20 \%$ because, for the baseline calibration, it is largest drop for which fiscal policy can be used to permanently restore full employment.

The effect of a $20 \%$ drop in the value of assets is to shift both the ME and NA curves to the left by $20 \%$. For the baseline calibration in which the initial level of government debt is zero, GDP falls by $20 \%$ and the real interest rate is left unchanged. A natural question is, Can fiscal policy move the economy back towards the social optimum?

Point $\mathrm{C}$ on Figure 2 represents the effect of a permanent increase in government purchases, financed by raising taxes on labor income. To restore full employment in the baseline calibration, government must increase expenditure from zero to 0.47 wage units (recall that the wage is the numeraire). This is is equivalent to an increase of $61 \%$ of full employment GDP and it must be paid for by increasing the tax rate on labor income from $0 \%$ (the baseline assumption) to $93 \%$. Since I assume no capital taxes and no outstanding debt, $93 \%$ of labor's share is equal to $61 \%$ of full employment GDP and is sufficient to just keep the government budget balanced. This is a huge fiscal expansion, far larger than anything currently contemplated. It is also an expansion that the agents in this model would oppose since it is unambiguously welfare decreasing.

Consider the effect of the stimulus on consumption which, in the absence of government debt, is an unambiguous measure of welfare. The initial drop in the value of the stock market of $20 \%$ causes a $20 \%$ fall in consumption, which in the baseline scenario, is initially equal to GDP. In the textbook Keynesian model of Samuelson (1955), an increase in government expenditure raises consumption through a multiplier effect that works through income. The multiplier is larger than 1. In a model with a single Ricardian household, a one dollar increase in government expenditure lowers consumption 
by one dollar. In the Ricardian model the multiplier is zero. The perpetual youth model lies between these two cases and for the baseline experiment the balanced budget multiplier is $1 / 3$.

How would the average household compare its life before and after the fiscal stimulus? Before the stimulus the household receives no benefit from government purchases and pays zero income taxes. Because of the stock market crash, the household consumes only $80 \%$ of the flow of goods it enjoyed previously and the number of unemployed household members increases by $20 \%$. After the fiscal stimulus, the unemployment rate is back to its efficient rate, and household income has gone up by $20 \%$. The stimulus also raises the risk free interest rate from $4.0 \%$ to $5.0 \%$.

Is the household happy with the stimulus plan? It is certainly true that full employment has been restored but, in this model, that is not a good indicator of welfare. I have assumed that government purchases yield no direct utility to the household. Under this assumption, the household is not happy because it is earning only 7 cents on every dollar of wage income earned. The rest goes to the government in the form of additional taxes. Before the fiscal stimulus the household was consuming $80 \%$ of full employment GDP. After the stimulus, it consumes only $39 \%$. The additional $61 \%$ of full employment GDP is spent by government and paid for with a $93 \%$ tax on labor income.

\section{Robustness to Alternative Calibrations}

Table 1 studies the robustness of these results to changes in the baseline calibration. The model has three parameters, $\pi, \beta$, and $\alpha$. Table 1 keeps $\alpha$ fixed at 0.34 which implies that labor's share will equal $2 / 3$, a number that is standard in the literature and consistent with a century of U.S. data. In the baseline calibration, I set $\pi$ to 0.98 . This implies that every living household has an expected lifespan of 50 years. This number was chosen to line up with the average lifespan of an American in 2008 by breaking the population 
into age deciles and averaging the life expectancy of each decile, weighted by the number in each group. A rough calculation using this method yields an average life expectancy of 48 years.

In representative agent models, the discount factor is chosen to match an average annual real interest rate of $3 \%$. In the perpetual youth model there is no longer a one-to-one mapping between $\beta$ and the interest rate since uncertain lifetimes cause agents to discount the future at a higher rate. Table 1 reports results for two different discount factors, $\beta=1$ and $\beta=0.97$. For each of these discount factors I report the value of the fiscal multiplier for four different assumptions about the value of $\pi$ that correspond to average life expectancies of 67 years, 50 years, 20 years and 12.5 years.

\begin{tabular}{|c|c|c|c|c|c|c|c|}
\hline $\begin{array}{c}\text { Discount } \\
\text { Factor }\end{array}$ & $\begin{array}{c}\text { Life } \\
\text { exptcy. } \\
\text { (Years) }\end{array}$ & $\begin{array}{c}\text { Stim- } \\
\text {-ulus } \\
(\% \\
\text { of GDP) }\end{array}$ & $\begin{array}{c}\text { Tax } \\
\text { Incr. } \\
\text { (\% wage } \\
\text { Inc.) }\end{array}$ & $\begin{array}{l}\text { Cons. } \\
\text { Drop } \\
\text { (\% of } \\
\text { GDP) }\end{array}$ & $\begin{array}{l}\text { Mult } \\
\text { iplier }\end{array}$ & $\begin{array}{l}\text { Opt. } \\
\text { Int. } \\
\text { Rate } \\
(\%)\end{array}$ & $\begin{array}{c}\text { New } \\
\text { Int } \\
\text { Rate } \\
(\%)\end{array}$ \\
\hline$\beta=0.97$ & 67 & 67 & 100 & -47 & 0.30 & 3.7 & 4.7 \\
\hline$\beta=1$ & & 36 & 54 & -16 & 0.56 & 0.9 & 1.1 \\
\hline$\beta=0.97$ & 50 & 61 & 93 & -41 & 0.33 & 4.0 & 5.0 \\
\hline$\beta=1$ & & 36 & 54 & -16 & 0.56 & 1.2 & 1.5 \\
\hline$\beta=0.97$ & 20 & 47 & 72 & -27 & 0.43 & 5.8 & 7.2 \\
\hline$\beta=1$ & & 36 & 54 & -16 & 0.56 & 3.0 & 3.8 \\
\hline$\beta=0.97$ & 12.5 & 43 & 65 & -23 & 0.47 & 7.7 & 9.6 \\
\hline$\beta=1$ & & 35 & 53 & -15 & 0.57 & 5.0 & 6.2 \\
\hline
\end{tabular}

Table $1 \quad$ Effects of a Fiscal Stimulus (Baseline Case in Bold)

The two rows in bold correspond to the most plausible case of a lifeexpectancy of 50 years for two different values of the discount factor. For a discount factor of 0.97 , the interest rate is $4 \%$ and for a discount factor of 1 , it is equal to $1.2 \%$. Notice, from this table, that the multiplier is never larger than 1 and that for the parameters in the table it varies in a relatively small 
range between 0.3 and 0.57 .

If one were to choose the discount factor to hit a target interest rate of $3 \%$, the discount factor would lie in the interval $[0.97,1]$. It follows that the most plausible value for the multiplier in this model is somewhere between 0.33 , when $\beta=0.97$ and 0.56 , when $\beta=1$. The first case would lead to a steady state interest rate of $4 \%$ and the latter would lead to a steady state interest rate of $1.2 \%$.

\section{Are Borrowers Constrained?}

If the model I have laid out in this paper is a good characterization of the real world, then a fiscal stimulus is unambiguously welfare decreasing. This conclusion rests on two assumptions that critics may challenge. First, I have assumed that credit markets work well and that households can borrow or

lend freely. Second, I have assumed that government purchases yield zero utility. Both assumptions are open to debate.

To many readers, the assumption of perfect credit markets will not seem like a good characterization of the 2008 financial crisis. Critics will point to the fact that in 2009 there was in excess of $\$ 900$ billion in excess reserves in the US banking system. But the fact that banks chose not to lend to borrowers does not mean that they were constrained from doing so. Indeed, there is considerable evidence that households and firms chose not to borrow.

There is another plausible explanation for the 2008 credit crunch. Lenders and borrowers were equally concerned that the value of physical assets would fall further. If house prices were to fall further, mortgage defaults would rise. If the value of the capital stock were to fall further, capital rental rates would drop and corporate revenue streams would be insufficient to meet fixed loan obligations. The problem in this scenario is not one of liquidity constraints; it is one of potential insolvency.

This is consistent with the view I have advanced in this paper in which 
credit markets function smoothly, but sometimes a lack of confidence results in the self-fulfilling belief that the economy will move to a high unemployment equilibrium. In order for a borrower and a lender to agree to a lending contract, both sides of the contract must agree that there is future income to borrow against. In an insolvency crisis, future income streams dry up and it is this self-fulfilling belief about the value of assets that is the problem, not a barrier to lending.

\section{What Does Data Say About the Size of the Multiplier?}

If credit markets function well, consumption should depend on wealth, not on income. It follows that increased government purchases will crowd out consumption and the multiplier will be less than one. If credit markets function poorly, then perhaps a fiscal expansion can relax credit market constraints and, in this case, one might construct models in which the multiplier is larger than one. To resolve this issue, it is natural to look to data for evidence of the size of the fiscal multiplier.

Unfortunately, there is no consensus on the facts since the empirical evidence is mixed. Using identified vector autoregressions, Blanchard and Perotti (2002) and Monacelli and Perotti (2008) find that consumption increases in response to a government expenditure shock. Ramey and Shapiro (1998) use a narrative approach to identify government expenditure shocks and find that consumption falls. Who should we believe?

The most recent contribution to this debate is a paper by Valerie Ramey (2008) which uses historical evidence from articles in Business Week to show that war-time expenditure shocks are predictable. By taking account of this narrative data Ramey is able to explain the VAR evidence that the consumption multiplier is larger than one as an artifact of the timing. If Ramey is correct, and she makes a persuasive case, the nays have it. An 
increase in government purchases crowds out private consumption.

\section{Is Government Expenditure Wasteful?}

I have argued that a stimulus will reduce welfare because it lowers consumption. But suppose that government purchases yield utility. Could it be that the loss in consumption is dominated by the gain in welfare from increased government programs? Although that may be true for some parameter values, it does not seem to be plausible under reasonable assumptions.

Consider an economy with one unit to allocate and suppose that welfare is given by the Cobb-Douglas function

$$
U=c \times(1+g)
$$

where

$$
c+g=y=1 \text {. }
$$

Think of $g$ as deviations from the optimal size of government. This utility function is ordinally equivalent to an additively separable logarithmic function with equal weights on consumption and government purchases. For this utility function, the household would choose $g=0$ if had only one unit of income to allocate and its utility would equal

$$
U^{A}=1 \times 1=1
$$

This ordinal representation of utility is useful because we can directly compare utility units with consumption units in the baseline case when $g=0$.

For example, suppose that as a result of a self-fulfilling drop in expectations, $y$ falls to 0.8 and excess government expenditure remains at 0 . In this case, household utility will drop from $U^{A}$ to $U^{B}$ where

$$
U^{B}=0.8<U^{A}=1
$$


The household in state $B$ has lost $20 \%$ of consumption and we can state directly that it would need to be compensated with 0.2 units of consumption to return to the same utility that it had in state $A$.

Now suppose the household is offered the bargain suggested by the fiscal expansion in the baseline calibration studied in this paper. Starting from state $B$ with 0.8 units of consumption and 0 units of the government good, the household can choose to receive an additional 0.61 units of government goods if it is willing to give up 0.41 units of private consumption goods. Would it be willing to accept this deal? Call this third situation state $C$. Utility in this state is given by

$$
U^{C}=0.39 \times 1.61=0.63<U^{B}=0.8<U^{A}=1 .
$$

In other words, restoring full employment with a balanced budget fiscal expansion would cost the household an additional $17 \%(0.8-0.63)$ in units of consumption. This is a policy that the household would vote against if given the option.

\section{Are There Better Alternatives?}

The need for fiscal policy depends on how efficiently markets allocate resources. The current policy debate is split between economists who advocate a large fiscal stimulus and those who are opposed. Those who favor a fiscal stimulus are, on the whole, believers in the proposition that the free market can sometimes deliver grossly inefficient outcomes. Opponents of a fiscal stimulus plan are believers in laissez-faire.

My position is nonstandard. My model is one in which sometimes the free market may break down. But it is also one that does not support a large fiscal stimulus as the best solution. My analysis suggests that replacing private expenditure by government expenditure, without restoring confidence in the stock market, can restore full employment. But the cost of this policy 
is likely to be substantial. Is there a way of restoring full employment without reducing welfare?

A fiscal stimulus is ineffective in my model because it can shift one of the equilibrium relationships, but not the other. In terms of Figure 2, a fiscal expansion shifts the ME curve to the right but leaves the NA curve in its depressed state. As a consequence, the interest rate rises and crowds out private consumption expenditure. I see two possible resolutions to this problem.

First, an investment tax credit that changes the trade-off between holding private capital and government debt would act to shift the NA curve to the right. In combination with a fiscal expansion, this seems to be a promising avenue to explore.

Second, an extension of the quantitative easing that has been engaged in by national central banks throughout the world holds some promise to directly influence asset markets. An extension of this policy would involve the direct intervention of central banks in national stock markets by offering to exchange government debt for private equity at a fixed price.

Many observers believe that the stock market and housing prices, in the last decade, were overvalued. But even though the market fell considerably in 2008, in the fall of 2009 households and firms were still holding substantial liquid assets. I believe this was because market participants were afraid that asset prices would fall even further. One way to restore confidence to the markets would be to place a floor and a ceiling on the value of the stock market by making a credible announcement that the central bank will intervene to keep an index value for stocks within preannounced bounds.

In the model, a market support policy would be sustained by an announcement that the price of capital will be supported at $p_{k}^{*}$. The predicted effect in the model is to increase the value of private wealth. In terms of Figure 2, it would shift the ME and NA curves to the right. Since debt and capital are perfect substitutes, a credible announcement would move the 
price to the announced price as a result of arbitrage by private traders. In theory, this policy should be credible even if the central bank never buys or sells an asset. In practice it may require active open market intervention by the central bank.

One concern is that interventions of this kind would interfere with the traditional central bank role of maintaining price stability. But there is no reason for an intervention of the kind I am suggesting to influence the money supply. By issuing its own interest bearing securities, the Fed could in principle, sterilize the effects of stock market interventions from influencing the size of the monetary base. By varying the size of the monetary base, the Fed would influence overnight interest rates to target inflation. By varying the composition of its balance sheet it would influence the value of the stock market to target unemployment.

\section{Conclusion}

We are at a time in history when established assumptions about macroeconomics are being questioned. There are many voices in the debate. Most arguments are informed either by a classical model in which free markets are assumed to be optimal or by the new-Keynesian model in which market failure occurs as a consequence of the assumption that prices are sticky. This paper has presented an alternative.

In my work, a stock market crash is caused by a self-fulfilling crisis of confidence that moves the economy from a low unemployment equilibrium to a high unemployment equilibrium. Multiple equilibria are possible because of a well defined market failure that follows from costly search and recruiting. Although this is a model in which the market is not self-correcting, fiscal policy is not an effective way of alleviating the problem. It is my hope that this paper will prompt more careful quantitative model-based analysis using the old-Keynesian framework. The model I propose can be estimated or cali- 
brated to provide quantitative assessments of the likely success of alternative strategies and it allows one to assess the costs and benefits of a fiscal stimulus against the alternatives. 


\section{A Appendix: Aggregate Consumption}

This appendix derives Equation (33). Let $\mathcal{A}_{t}$ be the set of agents alive at date $t$ and $\mathcal{A}_{t+1}$ be all agents alive at date $t+1$. Define aggregate human wealth as

$$
h_{t}=\sum_{h \in \mathcal{A}_{t}} h_{t}^{h}
$$

Sine all agents have the same human wealth and there is a unit measure of agents it follows that aggregate human wealth follows the same recursion as individual human wealth,

$$
h_{t}=\left(1-\tau_{t}\right) L_{t}+\pi Q_{t}^{t+1} h_{t+1} .
$$

Next, consider the budget constraint, Equation (28), which may be aggregated over all agents alive at date $t$ to give the expression,

$$
A_{t+1}=\frac{1}{Q_{t}^{t+1}}\left[A_{t}+\left(1-\tau_{t}\right) L_{t}-C_{t}\right]
$$

The term $\pi$ is missing from this expression because the assets of the fraction $(1-\pi)$ of agents who die in period $t$ are distributed to the agents who survive. That is,

$$
\sum_{h \in \mathcal{A}_{t}} \pi A_{t+1}^{h}=A_{t+1}
$$

Aggregating the policy function, Equation (30), across agents gives,

$$
C_{t}=(1-\beta \pi)\left[h_{t}+A_{t}\right]
$$


Rearranging Equation (61), substituting it into (58), and making use of (59) gives the following expression,

$$
\begin{aligned}
\frac{C_{t}}{(1-\beta \pi)}-A_{t} & =\left(1-\tau_{t}\right) L_{t} \\
& +\pi Q_{t}^{t+1}\left[\frac{C_{t+1}}{1-\beta \pi}-\frac{1}{Q_{t}^{t+1}}\left(A_{t}+\left(1-\tau_{t}\right) L_{t}-C_{t}\right)\right],
\end{aligned}
$$

which can be rearranged to give

$$
C_{t}\left(\frac{1-\pi(1-\beta \pi)}{1-\beta \pi}\right)=\left(\left(1-\tau_{t}\right) L_{t}+A_{t}\right)(1-\pi)+\frac{\pi Q_{t}^{t+1} C_{t+1}}{(1-\beta \pi)}
$$

Define the following constants:

$$
\tilde{\beta}=\frac{1-\pi(1-\beta \pi)}{\pi}, \quad \tilde{\alpha}=\frac{(1-\beta \pi)(1-\pi)}{1-\pi(1-\beta \pi)},
$$

and notice that

$$
A_{t}=B_{t}+\left(p_{k, t}+r r_{t}\right)
$$

Using the fact that $L_{t}+r r_{t}=Z_{t}$ from the national income accounting identity, we have the following intermediate expression,

$$
L_{t}+A_{t}=p_{k, t}+B_{t}+Z_{t}
$$

Substituting this into Equation (63) and making use of definition (64) and of the interest factor

$$
R_{t} \equiv \frac{1}{Q_{t}^{t+1}}
$$

yields the result,

$$
C_{t}=\frac{C_{t+1}}{R_{t} \tilde{\beta}}+\tilde{\alpha}\left(Z_{t}+p_{k, t}+B_{t}-\tau_{t} L_{t}\right)
$$

which is the equation we seek. 


\section{References}

BArro, R. J. (1974): “Are Government Bonds Net Wealth?," Journal of Political Economy, 82(6), 1095-1117.

Baxter, M., And R. G. King (1993): "Fiscal Policy in General Equilibrium," American Economic Review, 83(3), 315-334.

Benassy, J. P. (1975): "Neo-Keynesian disequilibrium theory in a monetary economy," The Review of Economic Studies, 42, 503-523.

Blanchard, O. J. (1985): "Debts, Deficits, and Finite Horizons," Journal of Political Economy, 93(April), 223-247.

Blanchard, O. J., and R. Perotti (2002): "An Empirical Characterization of the Dynamic Effects of Changes in Government Spending and Taxes on Output," Quarterly Journal of Economics, 117, 1329-1368.

Brown, A. (2010, expected): "Three Essays in Macroeconomics (Working title)," Ph.D. thesis, UCLA.

Burnside, C., M. Eichenbaum, and J. Fisher (2004): "Fiscal Shocks and their Consequences," Journal of Economic Theory, 115, 89-117.

Christiano, L., M. Eichenbaum, and S. Rebelo (2009): "When is the Government Spending Multiplier Large," NBER Working Papers 15394.

Clarida, R., J. Galí, and M. Gertler (1999): "The Science of Monetary Policy: A New Keynesian Perspective," Journal of Economic Literature, 37(December), 1661-1707.

Davig, T., And E. Leeper (2009): "Monetary-fiscal intertactions and fiscal stimulus," NBER Working Paper 15133.

Diamond, P. A. (1982a): "Aggregate Demand Management in Search Equilibrium," Journal of Political Economy, 90, 881-94. 
- (1982b): "Wage determination and efficiency in search equilibrium," Review of Economic Studies, 49, 217-227.

_ (1984): "Money in Search Equilibrium," Econometrica, 52, 1-20.

Dreze, J. H. (1975): "Existence of an exchange economy with price rigidities," Interntaional Economic Review, 16, 310-320.

Eggersston, G. B., And M. Woodford (2002): "The zero bound on interest rates and optimal monetary policy," Brookings Papers on Economic Activity, 2, 139-211.

FArmer, R. E. A. (2006): "Old Keynesian Economics," UCLA mimeo.

— (2008): "Aggregate Demand and Supply," International Journal of Economic Theory, 4(1), 77-94.

— (2009): "Confidence, Crashes and Animal Spirits," NBER WP no. 14846 .

- (2010): Expectations, Employment and Prices. Oxford University Press, forthcoming, New York.

Farmer, R. E. A., and A. Hollenhorst (2004): "Shooting the Auctioneer," UCLA mimeo.

Friedman, M. (1968): "The Role of Monetary Policy," American Economic Review, 58(March), 1-17.

Gertler, M., L. Sala, and A. Trigari (forthcoming): "An Estimated DSGE Model with Unemployment and Staggered Wage Bargaining," Journal of Money Credit and Banking.

Gertler, M., and A. Trigari (forthcoming): "Unemployent Fluctuations with Staggered Nash Wage Bargaining," Journal of Political Economy. 
Hagedorn, M., and I. Manovskin (2008): "The Cyclical Behavior of Equilibrium Unemployment and Vacancies Revisited," American Economic Review, 98(4), 1692-1706.

Hall, R. E. (2005a): "Employment Efficiency and Sticky Wages: Evidence from Flows in the Labor Market," The Review of Economics and Statistics, 87(3), 397-407.

Hall, R. E. (2005b): "Employment Fluctuations with Equilibrium Wage Stickiness," American Economic Review, 95(1), 50-65.

Hall, R. E., and P. Milgrom (forthcoming): "The Limited Influence of Unemployment on the Wage Bargain," American Economic Review.

Howitt, P. (1986): "The Keynesain Recovery," The Canadian Journal of Economics, 19(4), 626-641.

Howitt, P., And R. P. McAfee (1987): "Costly Search and Recruiting," International Economic Review, 28(1), 89-107.

Keynes, J. M. (1936): The General Theory of Employment, Interest and Money. MacMillan and Co.

Kydland, F. E., and E. C. Prescott (1982): "Time to Build and Aggregate Fluctuations," Econometrica, 50, 1345-1370.

Long, J. B., And C. I. Plosser (1983): "Real Business Cycles," Journal of Political Economy, 91(1), 39-69.

Malinvaud, E. (1977): The theory of unemployment reconsidered. Basil Blackwell, Oxford.

Monacelli, T., and R. Perotti (2008): "Fiscal Policy, Wealth Effects and Markups," NBER Working Paper 14584. 
Mortensen, D. T. (1984): "The Matching Process as a Non-Cooperative Bargaining Games," in The Economics of Information and Uncertainty, ed. by J. J. McCall, pp. 233-254, Chicago. University of Chicago Press for N.B.E.R.

Pissarides, C. (1984): "Search Intensity, Job Advertising and Efficiency," Jouurnal of Labor Economics, 2, 128-143.

_ (1990): Equilibrium Unemployment Theory. Basil Blackwell, Oxford.

Ramey, V. A. (2008): "Identifying government spending shocks; it's all in the timing," Mimeo, University of California San Diego.

Ramey, V. A., and M. Shapiro (1998): "Costly Capital Reallocation and the Effects of Government Spending," Carnegie Rochester Conference on Public Policy, 48, 145-194.

Samuelson, P. A. (1955): Economics: An Introductory Analysis (3rd Ed.). McGraw Hill.

Shimer, R. (2005): "The Cyclical Behavior of Equilibrium Unemployment and Vacancies," American Economic Review, 95(1), 25-49.

Weil, P. (1989): "Overlapping Generations of Infinitely Lived Agents," Journal of Public Economics, 38, 183-198.

YAARI, M. E. (1965): "Uncertain Lifetime, Life Insurance, and the Theory of the Consumer," Review of Economic Studies, 32, 137-150. 